\title{
Postnatal overnutrition programs the thyroid hormone metabolism and function in adulthood
}

\section{Patricia C Lisboa, Ellen P S Conceição, Elaine de Oliveira and Egberto G Moura}

Laboratory of Endocrine Physiology, Department of Physiological Sciences, Roberto Alcantara Gomes Biology Institute, State University of Rio de Janeiro, Avenida 28 de setembro, 87, Rio de Janeiro, RJ 20551-031, Brazil
Correspondence should be addressed to P C Lisboa Email pclisboa@uerj.br

\begin{abstract}
Early overnutrition (EO) during lactation leads to obesity, leptin resistance and lower thyroid hormone (TH) levels during adulthood. To better understand the biological significance of this thyroid hypofunction, we studied the long-term effects of postnatal EO on both the function of hypothalamic-pituitary-thyroid (HPT) axis and the metabolism and action of TH. To induce EO, the litter size was reduced to three pups per litter (small litter (SL) group) on the third day of lactation. In the controls (normal litter group), litter size was adjusted to 10 pups per litter. Rats were killed at PN180. TRH content and in vitro TSH were evaluated. lodothyronine deiodinase (D1 and D2) activities were measured in different tissues. Mitochondrial $\alpha$-glycerol-3-phosphate dehydrogenase (mGPD), uncoupling protein 1 (UCP1) and TH receptor (TR $\beta 1$ ) were evaluated to assess TH action. The SL group presented lower TRH, intra-pituitary and released TSH levels, despite unchanged plasma TSH. They presented lower D1 activity in thyroid, muscle and white adipose tissue (WAT) and higher D2 activity in the hypothalamus, pituitary, brown adipose tissue (BAT) and WAT, which confirmed the hypothyroidism. UCP1 in BAT and TR $\beta 1$ in WAT were decreased, which can contribute to a lower catabolic status. Despite the lower TH, the D2 activity in the thyroid, heart and testes was unchanged. Hepatic D1, mGPD and TR $\beta 1$ were also unchanged in SL rats, suggesting that the TH conversion and action were preserved in the liver, even with lower TH. Thus, this model indicates that postnatal EO changes thyroid function in adult life in a tissue-specific way, which can help in the understanding of obesogenesis.
\end{abstract}

\author{
Key Words \\ - overnutrition \\ - lactation \\ - hypothyroidism \\ - deiodinase \\ - programming
}

\section{Introduction}

The high prevalence of childhood obesity is considered a worldwide health problem. In addition to genetic factors, epigenetic factors can contribute to this epidemic. Epidemiological, clinical and experimental studies have shown that the nutritional, hormonal and environmental factors observed in the early stages of development have long-term effects on hormonal and metabolic homeostasis. This association can be characterized as a metabolic programming phenomenon, which is defined as an association between physical and chemical stimuli in early life and future functional status (de Moura et al. 2008).

Overnutrition during lactation represents a risk factor for obesity, diabetes and cardiovascular diseases. Animals raised in small litters have hyperphagia, obesity, hypertriglyceridemia and hyperinsulinemia at adulthood. 
Thus, these animals make good models for metabolic syndrome programmed by early-life overnutrition (Plagemann et al. 1992). Our group proved that postnatal early overnutrition (EO) programs for thyroid dysfunction, which is characterized by low $\mathrm{T}_{4}$ and $\mathrm{T}_{3}$ serum levels, which may, in turn, be related to the changes in the leptinsignaling pathway in hypothalamic-pituitary-thyroid (HPT) axis (Rodrigues et al. 2009). It is well known that a disturbance in thyroid function is associated with marked changes in both energy expenditure and body weight. However, to date, there has been no evidence regarding whether this hypothyroidism has biological significance in the EO model.

The enzyme $5^{\prime}$-iodothyronine deiodinase is responsible for the conversion of $\mathrm{T}_{4}$ to $\mathrm{T}_{3}$. In other words, this enzyme regulates tissue and serum TH availability. Based on some functional criteria, tissue-specific distribution and protein sequences, $5^{\prime}$-deiodinases are classified as two enzymes: type 1 (D1) and 2 (D2). In rodents, D1 is mainly detected in the liver, thyroid and kidney, and it generates most of the circulating $\mathrm{T}_{3}$, whereas $\mathrm{D} 2$ is mainly found in target tissues, such as the brain, pituitary and brown adipose tissue (BAT), and catalyzes the local $\mathrm{T}_{4}$ to $\mathrm{T}_{3}$ conversion. However, according to our current understanding, D1 and D2 make similar contributions to plasma $\mathrm{T}_{3}$ production. In hypothyroidism, a decrease in D1 and an increase in D2 occur; conversely, the opposite effect was found to occur in hyperthyroidism (Bates et al. 1999, Bianco \& Kim 2006, St Germain et al. 2009). To our knowledge, there are no data regarding the profiles of deiodinases in $\mathrm{EO}$ animals.

Therefore, we aimed to investigate the long-term effects of postnatal EO on thyroid hormone (TH) metabolism by evaluating the D1 and D2 activities in different tissues. By investigating these long-term effects, we can enhance our understanding regarding the degree of hypothyroidism previously reported in EO animal models. Because circulating thyrotropin (TSH) was unaltered in adult small litter (SL) rats, we evaluated the thyrotropin release hormone (TRH) in the hypothalamus, the TSH in the pituitary gland and the in vitro TSH secretion both under basal conditions and after TRH stimulation. Additionally, we studied the uncoupling protein 1 (UCP1) in BAT and the mitochondrial $\alpha$-glycerol-3phosphate dehydrogenase (mGPD) activity in the liver, which are both TH-dependent proteins, as well as the expression of $\beta 1$ isoform of the TH receptors (TR $\beta 1$ ) to better address the $\mathrm{TH}$ action in liver and adipose tissue in this programming model. We hypothesized that changes in TH metabolism, action and function can lead to a lower metabolic rate in this experimental model, which can help explain the development of obesity.

\section{Materials and methods}

Our experimental protocol was approved by the Animal Care and Use Committee of the Biology Institute of the State University of Rio de Janeiro, according to the Brazilian Law no. 11.794/2008. Wistar rats were housed in a temperature-controlled room with $12 \mathrm{~h}$ light: $12 \mathrm{~h}$ darkness cycle. Four-month-old virgin female rats were caged with a single male rat (3:1). During pregnancy and lactation, mothers were housed in individual cages and were administered water and a standard commercial diet ad libitum. To induce postnatal EO, 3 days after delivery, the litter size was adjusted to three male rats per each litter (SL) (Plagemann et al. 1992, Rodrigues et al. 2009). Litters containing ten pups per mother served as controls (normal litter, NL). After weaning (postnatal day-PN 21), all pups received standard chow. Body weight and food intake were measured until the day of sacrifice. One animal was randomly chosen from each litter and was used in the subsequent experiments, thus giving a total of 12 pups per group from 24 different litters $(\mathrm{SL}=12$ and $\mathrm{NL}=12$ ). Both groups were killed at PN180 by rapid decapitation with no prior anesthesia to collect blood, white adipose tissue (WAT), BAT, soleus (skeletal muscle), liver, hypothalamus, pituitary, thyroid, heart and testes.

\section{Visceral fat content}

Mesenteric, epididymal and retroperitoneal WAT were weighed for evaluation of central adiposity (Rodrigues et al. 2009).

\section{Plasma hormones measurement}

Blood was centrifuged $\left(1000 \mathrm{~g}, 30 \mathrm{~min}, 4^{\circ} \mathrm{C}\right)$ and plasma was stored at $-20^{\circ} \mathrm{C}$ until assay. Determinations were performed in one assay, and the samples were analyzed in duplicate. Plasma total $\mathrm{T}_{3}\left(\mathrm{TT}_{3}\right)$ and free thyroxine $\left(\mathrm{FT}_{4}\right)$ were measured by RIA (ICN Pharmaceuticals, Inc., Orangeburg, NY, USA). Plasma TSH was measured by specific RIA, using a rat TSH kit supplied by the National Institute of Health (NIH, St Louis, MO, USA) and expressed in terms of the reference preparation provided (RP-3). Limits of detection were $25 \mathrm{ng} / \mathrm{dl}$ for $\mathrm{T}_{3}, 0.3 \mathrm{ng} / \mathrm{dl}$ for $\mathrm{T}_{4}$ and $0.18 \mathrm{ng} / \mathrm{ml}$ for TSH and intra-assay variations were $3.6,7.5$ and $3.1 \%$ respectively.

Published by Bioscientifica Ltd. 


\section{Deiodinase activities measurement}

Tissues were dissected, kept in liquid nitrogen and immediately processed for enzymatic activity. D1 and D2 activities were measured in WAT, BAT, liver, hypothalamus, pituitary, thyroid, skeletal muscle, heart and testis homogenates (Tris-HCl $50 \mathrm{mM}, \mathrm{pH} \mathrm{6,8),} \mathrm{using} \mathrm{the}$ previously reported method based on the release of ${ }^{125} \mathrm{I}$ from ${ }^{125}$ I-reverse $T_{3}$ (PerkinElmer/NEN, Boston, MA, USA) (Bates et al. 1999, Lisboa et al. 2008). Assays were performed in phosphate buffer containing $1 \mathrm{mM}$ EDTA at $\mathrm{pH}$ 6.9. The $\mathrm{D} 1$ assay was performed in the presence of $1.5 \mu \mathrm{M}$ of $\mathrm{rT}_{3}, 10 \mathrm{mM}$ of DTT and $100 \mathrm{nM}$ of $\mathrm{T}_{4}$ (to inhibit D2). The D2 assay was performed with $2 \mathrm{nM} \mathrm{rT}_{3}, 40 \mathrm{mM}$ DTT and $1 \mathrm{mM}$ 6-n-propylthiouracil (PTU) (to inhibit D1). Equal aliquots of ${ }^{125} \mathrm{I}_{-} \mathrm{rT}_{3}$ were purified by paper electrophoresis and placed into each tube assay; the reaction was started by the addition of tissue samples. A blank tube was run in parallel with each assay and contained $50 \mu$ l of the substrate solution and $50 \mu \mathrm{l}$ of buffer, which had its values subtracted from the enzyme samples. Reactions were performed in a shaking-bath at $37^{\circ} \mathrm{C}$, and stopped after $30 \mathrm{~min}$ (D1 in liver and thyroid), $60 \mathrm{~min}$ (D2 in hypothalamus, pituitary and thyroid) or $120 \mathrm{~min}$ (D1 in soleus; D2 in WAT, BAT, heart and testis). These reactions were stopped by the addition of a mixture of $8 \%$ BSA and $10 \mathrm{mM}$ PTU, followed by cold $20 \%$ trichloroacetic acid. Samples were centrifuged $\left(1500 \mathrm{~g}, 4^{\circ} \mathrm{C}, 5 \mathrm{~min}\right)$ and $200 \mu \mathrm{l}$ of the supernatants were applied to Dowex $50 \mathrm{~W}$-X2 columns (100-200 mesh hydrogen form BioRad). Free ${ }^{125} \mathrm{I}$ eluted from columns with $10 \%$ acetic acid was measured in a $\gamma$-counter. The percent of deiodination in the presence of the enzyme was $\sim 10-20 \%$, and the nonspecific free ${ }^{125} \mathrm{I}$ represented $<1-2 \%$ of the total radioactivity in the mixture. The specific enzyme activity was expressed by fentomoles, picomoles or nanomoles of $\mathrm{rT}_{3}$ deiodinated/h $\mathrm{mg}$ of protein.

\section{mGPD activity measurement}

Because liver GPD reflects the TH action and is being considered a marker of thyroid status, we measured GPD activity in mitochondrial fraction using phenazine methosulfate (PMS) as an electron transporter between the reduced enzyme and iodonitrotetrazolium chloride violet (INT) (Oliveira et al. 2007). The assay was done with $0.1 \mathrm{M}$ DL- $\alpha$-glycerophosphate diluted in KCN/KPB and a solution of $7.9 \mathrm{mM}$ INT-0.12 mM PMS. Samples were analyzed at $500 \mathrm{~nm}$ and the values were expressed as absorbance (O.D)/mg of protein.

\section{Pituitary explants: secretion of basal TSH and post-TRH stimulation}

The in vitro TSH secretion was performed as previously reported (Lisboa et al. 2008). Six pituitaries of SL and NL rats were quickly dissected out and the anterior pituitary was separated from posterior pituitary and transected with a longitudinal midline cut (12 hemi-pituitary per group). Each anterior hemi-pituitary was immediately transferred to a tube that contained $1 \mathrm{ml}$ of minimum essential medium (MEM, Sigma-Aldrich), and was incubated at $37{ }^{\circ} \mathrm{C}$ in an atmosphere of $95 \% \mathrm{O}_{2}$ and $5 \% \mathrm{CO}_{2}$ in a Dubnoff metabolic shaker (50 cycles/min). After a 20-min preincubation period, the medium was removed and hemi-pituitaries were suspended in $1 \mathrm{ml}$ of fresh medium. After $60 \mathrm{~min}$, aliquots were collected to determine the basal TSH release. Next, TRH (Sigma-Aldrich) was added at a final concentration of $50 \mathrm{nM}$; after a 30-min incubation, aliquots were collected to determine the TRH-stimulated TSH release. At the end of the incubation period, each hemipituitary was homogenized in PBS, at $\mathrm{pH}$ 7.6, for intra-pituitary TSH content measurement. The TSH levels were measured by RIA as described above. The results are expressed as ng of TSH at basal conditions, as the difference between TSH release before and after TRH incubation and as $\mu \mathrm{g}$ of TSH per mg protein content of pituitary gland.

\section{TRH, UCP1 and TR $\beta 1$ protein content measurement}

The expression of TRH was detected in the hypothalamus, UCP1 was determined in BAT and TR $\beta 1$ was performed in the liver and WAT by western blotting, using $\beta$-actin as an internal control. The hypothalamus, BAT and liver were homogenized in ice-cold lysis buffer (50 mM HEPES, $1 \mathrm{mM}$ $\mathrm{MgCl}_{2}, 10$ mM EDTA, Triton X-100 1\%, pH 6.4) and WAT was homogenized in ice-cold lysis buffer $(20 \mathrm{mM}$ Tris-HCl, $10 \mathrm{mM} \mathrm{NaF}, 150 \mathrm{mM}, 5 \mathrm{mM}$ and 0,1\% SDS, pH 7.4), both of which contained Complete Protease Inhibitor Tablets (Roche Diagnostics Corporation). After centrifugation (7500 $\boldsymbol{g}$ for $5 \mathrm{~min}$ ), homogenates were stored at $-20^{\circ} \mathrm{C}$. Protein concentrations were determined using the BCA protein kit assay (Thermo Scientific, Rockford, IL, USA). Samples $(30 \mu \mathrm{g}$ total protein) were separated by $10 \%$ SDS-PAGE and transferred to nitrocellulose membranes (Hybond P ECL membrane; Amersham Pharmacia Biotech). Membranes were blocked with 5\% albumin in Tween-TBS (0.1\% Tween-20 and $20 \mathrm{mM}$ Tris-HCl, pH 7.5, $500 \mathrm{mM} \mathrm{NaCl}$ ) for $1 \mathrm{~h}$. Next, membranes were washed with TBS and incubated overnight with the following

Published by Bioscientifica Ltd. 
primary antibodies used: anti-TRH diluted 1:100 (LifeSpam Biosciences, Seattle, WA, USA, catalog number LSC76393); anti-UCP1 diluted 1:500 (Sigma-Aldrich, catalog number U6382); and anti-TR $\beta 1$ diluted 1:1000 (Santa Cruz Biotechnology, Inc. catalog number sc-10822). Subsequently, membranes were washed and incubated with proper secondary antibodies for $1 \mathrm{~h}$ at room temperature. Then, immunoreactive proteins were visualized by exposure to X-ray film. The density of the TRH, UCP-1 and TR $\beta 1$ bands was also quantified using the Image $J$ 1.34s Software (Wayne Rasband NIH, Boston, MA, USA).

\section{Statistical analysis}

The data were analyzed using the GraphPad Prism 5 program (GraphPad Software, Inc., La Jolla, CA, USA) and expressed as the mean \pm s.E.M. The results were analyzed using unpaired Student's t-tests, except for the TSH (Mann-Whitney $U$ test). Significance was assumed at the level of $P<0.05$.

\section{Results}

As expected, early overfeeding was associated with higher visceral adiposity during adulthood $(+65 \%$ retroperitoneal; $+51 \%$ epididymal; $P<0.05 ;+61 \%$ mesenteric; $P<0.01$; data not shown). At PN180, the SL rats presented lower plasma $\mathrm{T}_{3}(-25 \%)$ and $\mathrm{T}_{4}(-28 \%)$, but unchanged TSH levels (Table 1) compared with NL rats. These results are in agreement with the results obtained in a previous study (Rodrigues et al. 2009).

In the hypothalamus, the adult SL group showed a lower TRH content $(-22 \% ; P<0.05$; Fig. 1$)$. As depicted in

Table 1 Parameters of thyroid function of adult rats (PN180) in the programming model of postnatal early overnutrition. Results expressed as mean \pm s.E.M. of 12 rats per group, except for in vitro TSH measurements (six rats/12 hemi-pituitaries/ group). ${ }^{\star} P<0.05$

\begin{tabular}{|c|c|c|}
\hline & NL & SL \\
\hline Plasma $\mathrm{TT}_{3}(\mathrm{ng} / \mathrm{dl})$ & $97.06 \pm 6.87$ & $72.22 \pm 5.04 *$ \\
\hline Plasma $\mathrm{FT}_{4}(\mu \mathrm{g} / \mathrm{dl})$ & $2.89 \pm 0.24$ & $2.07 \pm 0.17 *$ \\
\hline Plasma TSH (ng/ml) & $0.32 \pm 0.05$ & $0.36 \pm 0.02$ \\
\hline Basal TSH release $(\mathrm{ng} / \mathrm{ml})$ & $1.86 \pm 0.59$ & $0.52 \pm 0.08 *$ \\
\hline $\begin{array}{l}\text { TRH-stimulated TSH release } \\
\quad(\mathrm{ng} / \mathrm{ml})\end{array}$ & $1.32 \pm 0.63$ & $0.93 \pm 0.28 *$ \\
\hline $\begin{array}{l}\text { Intra-pituitary TSH content } \\
(\mu \mathrm{g} / \mathrm{mg} \mathrm{ptn})\end{array}$ & $1.64 \pm 0.32$ & $0.62 \pm 0.08 *$ \\
\hline
\end{tabular}

$\mathrm{NL}$, normal litter; $\mathrm{SL}$, small litter; $\mathrm{TSH}$, thyrotropin; $\mathrm{FT}_{4}$, free thyroxine; $\mathrm{TT}_{3}$, total triiodothyronine.
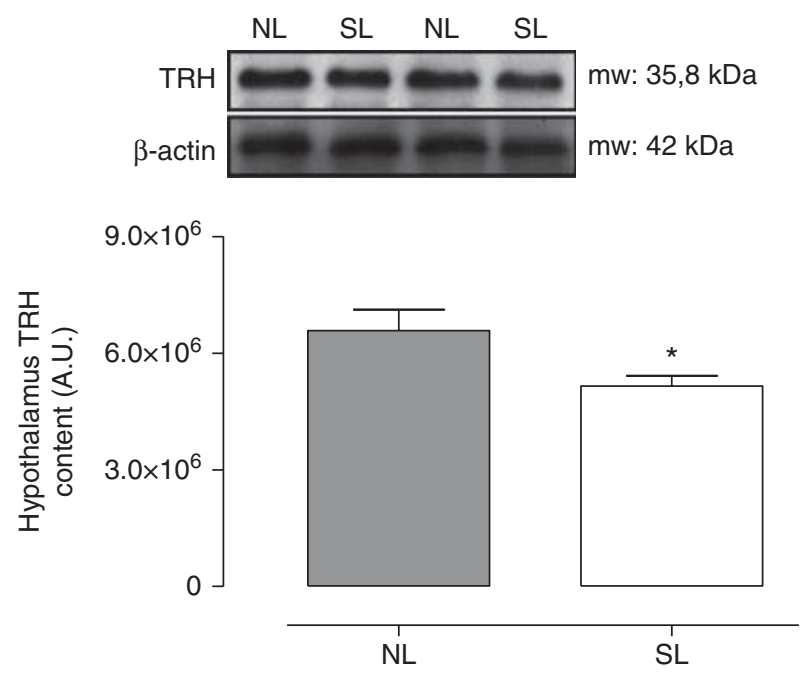

Figure 1

Hypothalamic TRH content protein expression in NL (gray bar; $n=12$ ) and SL (white bar; $n=12$ ) group at 180 days old. Bands on the top figure represent the protein expression in hypothalamus and pituitary homogenate from individual NL and SL animals. TRH and TSH content were quantified by scanning densitometry (arbitrary units (AU)); actin content was used as control loading. Graph represents a pool of two independent western blots. Data are reported as mean \pm s.E.M.; $n=12$ per group.

Table 1, pituitaries from the SL group presented a decrease in basal TSH release $(-72 \% ; P<0.05)$, a reduction of TSH release in response to TRH $(-30 \% ; P<0.05)$ and lower TSH tissue content $(-62 \% ; P<0.05)$ compared with controls.

In PN180, the SL group showed no change in D1 and mGPD activities or in TR $\beta 1$ protein expression in the liver (Fig. 2).

Concerning other deiodinase activities (Table 2), SL rats presented lower D1 activity in the thyroid $(-13 \%)$, WAT $(-64 \%)$ and skeletal muscle $(-59 \%)$, and higher D2 activity in th hypothalamus $(+76 \%)$, pituitary $(+17 \%)$, BAT $(+70 \%)$ and WAT $(+62 \%)$. Postnatal EO did not change D2 activity in the thyroid, heart and testis at adulthood (Table 2).

The protein expression of TR $\beta 1$ in WAT and UCP1 in BAT was lower in SL rats than in NL rats $(-53 \%$ and $-41 \%$; $P<0.05-$ Fig. 3 ).

\section{Discussion}

Nutritional factors influence the HPT axis, which regulates energetic metabolism and, consequently, body weight (Hollenberg 2008, Reinehr 2008, Pearce 2012). Previously, we showed that rats raised in small litters had secondary hyperthyroidism (higher serum $\mathrm{TSH}, \mathrm{T}_{4}$ and $\mathrm{T}_{3}$ ) at weaning, but that during adulthood, rats developed

Published by Bioscientifica Ltd. 

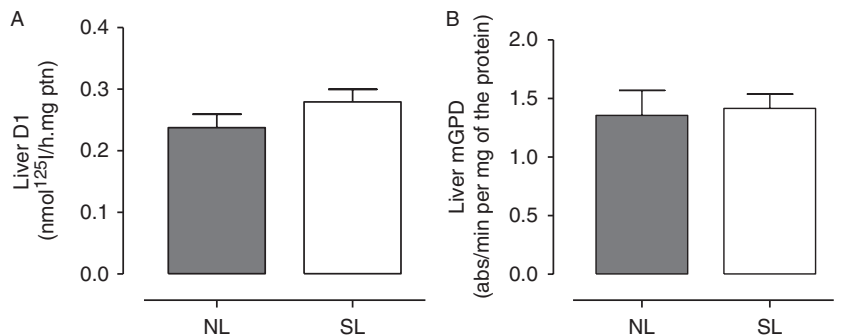

C
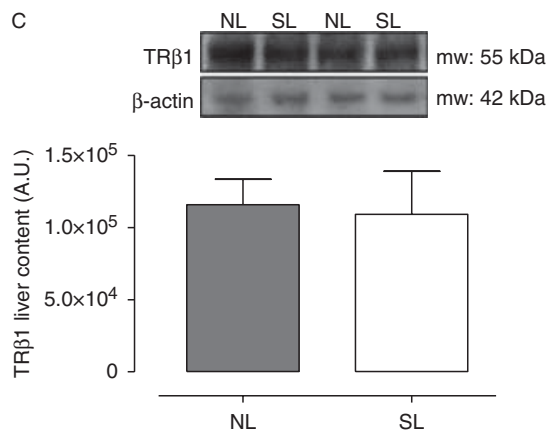

Figure 2

Liver D1 activity (A), mGPD activity (B) and TR $\beta 1$ protein expression (C) of NL (gray bar; $n=12$ ) and SL (white bar; $n=12$ ) groups at 180 days old. Bands on the top figure represent the proteins expression in homogenate from individual NL and SL animals. TR $\beta$ content was quantified by scanning densitometry (arbitrary units (AU)); actin content was used as control loading. Graph represents a pool of two independent western blots. Data are reported as mean \pm S.E.M.; $n=12$ per group.

lower serum total $\mathrm{T}_{3}$ and free $\mathrm{T}_{4}$ despite normal TSH (Rodrigues et al. 2009). In fact, some studies have shown that hyperthyroidism during lactation is associated with hypothyroidism in adult life (Walker \& Courtin 1985, Wilcoxon \& Redei 2004, Moura et al. 2008). These intriguing findings in the adult life of SL rats raised two main questions regarding the present study; i) does the programmed hypothyroidism functional? and ii) what is the cause for inappropriately low TSH? The current work shows the impact of postnatal EO and transient hyperthyroidism on late $\mathrm{TH}$ metabolism, action and function. We found that SL rats were programmed for central hypothyroidism. Here, the lower D1 activity in the thyroid, muscle and WAT and higher D2 activity in the hypothalamus, pituitary, BAT and WAT are in accordance with the hypothyroid status of the adult offspring. Because $\mathrm{TH}$ are important regulators of WAT storage through the regulation of adipocyte differentiation, lipogenic/lipolytic metabolism and mitochondrial activity (Pearce 2012), the lower TR $\beta 1$ content in WAT indicates that some of these processes were compromised, including adipogenesis, lipogenesis and lipolysis, and adipocytokine secretion. Additionally, the lower UCP1 content in BAT suggests a decrease in thermogenesis corroborating based on observed hypothyroid status.

Leptin directly stimulates TRH in the hypothalamic PVN nucleus as well as the production and secretion of TSH in the pituitary (Itoh et al. 2003). In PN180, although SL rats present normal TSH and leptin levels (Rodrigues et al. 2009, Conceição et al. 2011), they exhibited leptin resistance at the level of the hypothalamus and pituitary level (Rodrigues et al. 2009, Rodrigues et al. 2011). This finding is in agreement with the decrease observed in TRH protein expression in the hypothalamus and the decreased intra-pituitary TSH with lower basal and TRH-stimulated TSH secretion. Thus, we demonstrated that SL rats were programmed for a central hypothyroidism (low TRH). Although the plasma TSH can only be immunologically normal, its bioactivity could be lower, which would explain the lower plasma $\mathrm{T}_{4}$ and $\mathrm{T}_{3}$ levels and the possible decrease in TSH clearance. In fact, a high sialic acid content of TSH can reduce the biological activity of plasma TSH and increase its half-life (Miura et al. 1989, Horimoto

Table 2 Deiodinase activities of adult rats (PN180) in the programming model of postnatal early overnutrition. Results expressed as mean \pm s.E.M. of 12 rats per group. ${ }^{*} P<0.05$

\begin{tabular}{|c|c|c|}
\hline & NL & SL \\
\hline Hypothalamic D2 (fmol ${ }^{125} \mathrm{I} / \mathrm{h}$ mg ptn) & $91.3 \pm 3.9$ & $160.8 \pm 17.0 *$ \\
\hline Pituitary D2 (fmol ${ }^{125} \mathrm{I} / \mathrm{h} \mathrm{mg} \mathrm{ptn)}$ & $96.1 \pm 2.8$ & $112.2 \pm 5.0 *$ \\
\hline Thyroid D1 (nmol ${ }^{125} \mathrm{I} / \mathrm{h} \mathrm{mg} \mathrm{ptn)}$ & $6.2 \pm 0.2$ & $5.4 \pm 1.2 *$ \\
\hline Thyroid D2 (pmol ${ }^{125} \mathrm{I} / \mathrm{h} \mathrm{mg} \mathrm{ptn)}$ & $2.2 \pm 0.1$ & $2.2 \pm 0.2$ \\
\hline BAT D2 (fmol ${ }^{125} \mathrm{l} / \mathrm{h} \mathrm{mg}$ ptn) & $16.5 \pm 3.1$ & $28.1 \pm 3.2 *$ \\
\hline WAT D1 (nmol ${ }^{125} \mathrm{I} / \mathrm{h} \mathrm{mg} \mathrm{ptn)}$ & $63.8 \pm 14.9$ & $22.9 \pm 3.7 *$ \\
\hline WAT D2 (fmol ${ }^{125} \mathrm{I} / \mathrm{h}$ mg ptn) & $52.4 \pm 7.6$ & $84.8 \pm 9.3 *$ \\
\hline Muscle D1 (pmol ${ }^{125} \mathrm{l} / \mathrm{h} \mathrm{mg} \mathrm{ptn)}$ & $25.5 \pm 1.5$ & $10.5 \pm 0.9 *$ \\
\hline Heart D2 (fmol ${ }^{125} \mathrm{I} / \mathrm{h}$ mg ptn) & $14.9 \pm 0.8$ & $13.6 \pm 1.6$ \\
\hline Testis D2 (fmol ${ }^{125} \mathrm{I} / \mathrm{h} \mathrm{mg} \mathrm{ptn)}$ & $28.1 \pm 1.7$ & $26.7 \pm 4.2$ \\
\hline
\end{tabular}

NL, normal litter; SL, small litter; D1, type 1 deiodinase; D2, type 2 deiodinase; BAT, brown adipose tissue; WAT, white adipose tissue.

http://joe.endocrinology-journals.org DOI: 10.1530/JOE-15-0237
(C) 2015 Society for Endocrinology Printed in Great Britain
Published by Bioscientifica Ltd 
A

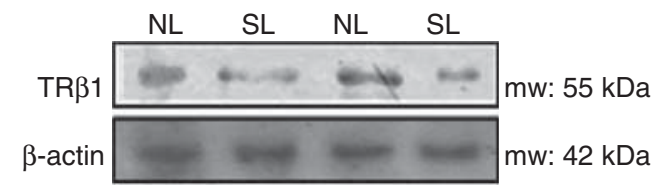

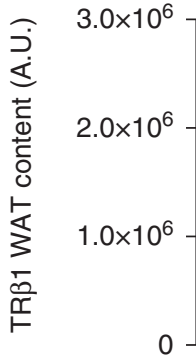

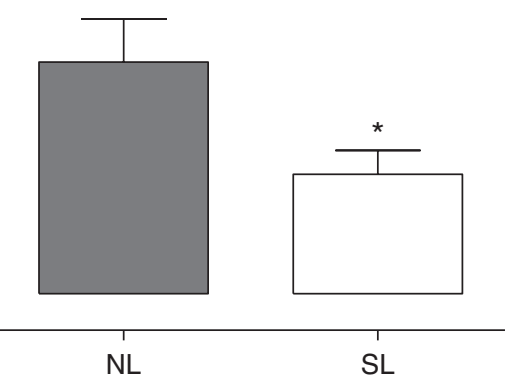

B

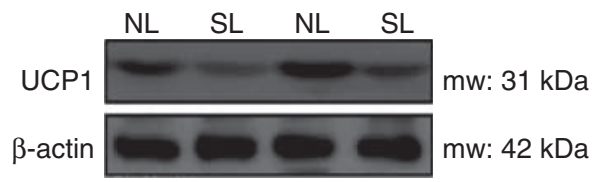

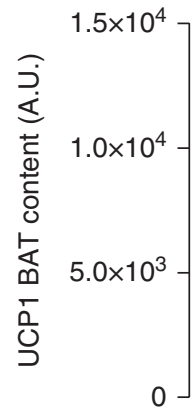

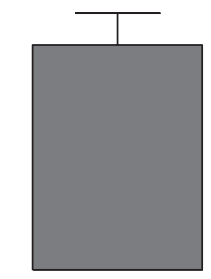

NL

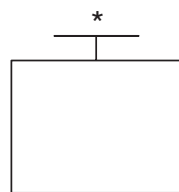

SL
Figure 3

TR $\beta 1$ protein expression in retroperitoneal WAT (A) and UCP-1 protein expression in BAT (B) of NL (gray bar; $n=12$ ) and SL (white bar; $n=12$ ) group at 180 days old. (C). Bands on the top figure represent the proteins expression in homogenate from individual NL and SL animals. Protein content was quantified by scanning densitometry (arbitrary units (AU)); actin content was used as control loading. Graph represents a pool of two independent western blots. Data are reported as mean \pm s.E.M.; $n=12$ per group.

et al. 1995, Persani et al. 1998, Garcia et al. 2014). In addition, the increase in pituitary D2 activity detected in SL rats may be partially responsible for the normal serum TSH levels.

The D2 activity in the thyroid, heart and testis were unchanged, despite the lower plasma $\mathrm{TH}$, which suggests that other factors that were programmed by postnatal EO are more important regulators of D2 than $\mathrm{TH}$ is, at least in these three tissues. Moreover, no study has been specifically designed to analyze the long-term consequences of postnatal EO on iodothyronine deiodinase activities in the adult progeny. In another programming model, we showed that nutritional and hormonal factors during lactation, such as protein malnutrition (Dutra et al. 2003, Lisboa et al. 2008), hyperleptinemia (Toste et al. 2006) and hypoprolactinemia (Bonomo et al. 2008) program changes in deiodinase activity during adult life, could be caused by either hyper- or hypothyroidism. In these experimental models, hyperleptinemia at weaning was also found in neonate SL rats (Rodrigues et al. 2009) and could be responsible for programming the $T_{4}$ to $T_{3}$ conversion in different tissues.

Interestingly, we found no change in liver D1, mGPD and TR $\beta 1$ in SL rats at PN180, which are well known positive TH-markers that should be decreased. This finding indicates that the intracellular conversion of $\mathrm{T}_{4}$ to $\mathrm{T}_{3}$ and the $\mathrm{TH}$ action were preserved in the liver in this programming model, even with lower plasma TH levels. Moreover, serum cholesterol, which must be higher in hypothyroidism, was unchanged in adult SL rats (Rodrigues et al. 2011).

The transport of $\mathrm{TH}$ into the liver across the cell membrane, which is required for its metabolism and action, has been studied in both humans and rats. In humans, fasting is associated with relatively normal serum TSH and low $\mathrm{T}_{3}$ levels and thus reflects a reduced peripheral $\mathrm{T}_{4}$ to $\mathrm{T}_{3}$ conversion as well as lower liver $\mathrm{TH}$ uptake (van der Heyden et al. 1986). In rodents, fasting decreases $\mathrm{TH}$ uptake in the liver and other tissues (Hennemann et al. 2001). The monocarboxylate transporter (MCT)-8, MCT10, and organic anion transporting polypeptide 1C1 (OATP1C1) are the best-characterized specific TH transporters (Alkemade et al. 2011). In fact, immunohistochemistry studies have shown the high expression of MCT8 in some tissues such as the liver, and MCT8 is thus considered an active and specific TH transporter (Friesema et al. 2003). To the best of our knowledge, there are few reports on the regulation of transporters by TH. Two studies suggested that the hypothyroidism caused by low iodine and low $\mathrm{T}_{3}$ syndrome leads to a compensatory increase in MCT8 (Hu et al. 2014), MCT10 and OATP1C (Mebis et al. 2009). Thus, in our programming model, it is possible that the intracellular $\mathrm{TH}$ was preserved, at least in the liver, by the higher TH uptake by transporters. Therefore, our data suggest that the SL rats developed an adaptive mechanism that ensured an adequate intracellular source of $\mathrm{TH}$ in the liver, which could explain the almost unchanged glucose and lipid homeostasis in SL animals. Thus, the current

Published by Bioscientifica Ltd. 
data invite further study concerning the regulation of the TH-transporters by $\mathrm{T}_{3}$ in different tissues.

It is well known that BAT thermogenesis through UCP1 expression is the most important non-shivering process to dissipate energy and generate heat in rodents. The ablation of UCP1 gene is able to induce obesity without hyperphagia (Lowell et al. 1993). The UCP1 mRNA expression is stimulated by the sympathetic nervous system (SNS) and leptin via the SNS (Commins et al. 1999, Cettour-Rose et al. 2002). It was also shown that central leptin administration, likely due to the influence of SNS, increased D2 mRNA expression and activity in BAT (Cettour-Rose et al. 2002). The thermogenesis reduction in young adult SL rats (8-week-old) has been reported (Xiao et al. 2007), which had decreased BAT UCP1 mRNA and lower $\beta 3$ adrenergic receptor expression and activation at room temperature and under cold exposition (adrenergic stimulus). Our current findings concerning BAT D2 activity and UCP1 protein content in PN180 SL rats support these previous data.

In BAT, both the D2 activity (+70\%) and UCP1 content $(-41 \%)$ of SL rats were consistent with their hypothyroid status. The higher D2 activity must be responsible for the local conversion of $T_{4}$ to $T_{3}$ in this tissue and, consequently, must increase UCP1 content. However, SL rats have lower $\mathrm{T}_{4}(-28 \%)$, which may not generate a sufficient amount of $\mathrm{T}_{3}$ to correct UCP1 to the control level. Although the D2 activity was almost doubled, this activity was evaluated in an in vitro assay, in which the optimal conditions for the enzyme activity were provided.

In summary, it is known that epigenetic mechanisms, such as DNA methylation, histone acetylation and deacetylation, or microRNA, induced by pre- and postnatal factors such as nutrition and hormones, may lead to a higher risk of metabolic diseases in the adult life of the offspring (de Moura et al. 2008). This explanation may help us understand the permanent changes of TRH, TSH, deiodinases, UCP- 1 and TR $\beta 1$ that are caused by EO. Therefore, it is possible that overfed children can be more susceptible to thyroid disorders in adult life, an issue that deserves further epidemiological and clinical investigation.

In fact, although the mechanisms involved remain unclear, overnutrition during lactation induces long-term effects on the regulation of the HPT axis and TH metabolism and action. There is a lack of clinical, epidemiological or even experimental studies regarding hypothyroidism in adulthood caused by postnatal and childhood overnutrition. For the first time, we have shown that the decreased TH levels observed in SL rats, although mild, are functional, thus contributing to a hypometabolic profile of these programmed overweight animals. Taken together, the present data reinforce the concept of the 'developmental origins of health and disease,' mainly concerning the programming of the thyroid function.

\section{Declaration of interest}

The authors declare that there is no conflict of interest that could be perceived as prejudicing the impartiality of the research reported.

\section{Funding}

This work was supported by the National Council for Scientific and Technological Development (Conselho Nacional de Desenvolvimento Científico e Tecnológico-CNPq), the Coordination for the Enhancement of Higher Education Personnel (Coordenação de Aperfeiçoamento de Pessoal de Nivel Superior-CAPES) and the State of Rio de Janeiro Carlos Chagas Filho Research Foundation (Fundação Carlos Chagas Filho de Amparo à Pesquisa do Estado do Rio de Janeiro-FAPERJ).

\section{Acknowledgements}

We thank Ulisses Siqueira and Mônica Moura for excellent technical assistance.

\section{References}

Alkemade A, Friesema EC, Kalsbeek A, Swaab DF, Visser TJ \& Fliers E 2011 Expression of thyroid hormone transporters in the human hypothalamus. Journal of Clinical Endocrinology and Metabolism 96 E967-E971. (doi:10.1210/jc.2010-2750)

Bates JM, St Germain DL \& Galton VA 1999 Expression profiles of the three iodothyronine deiodinases, D1, D2, and D3, in the developing rat. Endocrinology 140 844-850. (doi:10.1210/endo.140.2.6537)

Bianco AC \& Kim BW 2006 Deiodinases: implications of the local control of thyroid hormone action. Journal of Clinical Investigation 116 2571-2579. (doi:10.1172/JCI29812)

Bonomo IT, Lisboa PC, Passos MC, Alves SB, Reis AM \& de Moura EG 2008 Prolactin inhibition at the end of lactation programs for a central hypothyroidism in adult rat. Journal of Endocrinology 198 331-337. (doi:10.1677/JOE-07-0505)

Cettour-Rose P, Burger AG, Meier CA, Visser TJ \& Rohner-Jeanrenaud F 2002 Central stimulatory effect of leptin on $\mathrm{T}_{3}$ production is mediated by brown adipose tissue type II deiodinase. American Journal of Physiology. Endocrinology and Metabolism 283 E980-E987. (doi:10.1152/ ajpendo.00196.2002)

Commins SP, Watson PM, Padgett MA, Dudley A, Argyropoulos G \& Gettys TW 1999 Induction of uncoupling protein expression in brown and white adipose tissue by leptin. Endocrinology 140 292-300. (doi:10.1210/endo.140.1.6399)

Conceição EPS, Trevenzoli IH, Oliveira E, Franco JG, Carlos AS, Nascimento-Saba CC, Moura EG \& Lisboa PC 2011 Higher white adipocyte area and lower leptin production in adult rats overfed during lactation. Hormone and Metabolic Research 43 513-516. (doi:10.1055/ s-0031-1275702)

Dutra SC, Passos MC, Lisboa PC, Santos RS, Cabanelas AP, Pazos-Moura CC \& Moura EG 2003 Liver deiodinase activity is increased in adult rats whose mothers were submitted to malnutrition during lactation. 
Hormone and Metabolic Research 35 268-270. (doi:10.1055/s-200339485)

Friesema EC, Ganguly S, Abdalla A, Manning Fox JE, Halestrap AP \& Visser TJ 2003 Identification of monocarboxylate transporter 8 as a specific thyroid hormone transporter. Journal of Biological Chemistry 278 40128-40135. (doi:10.1074/jbc.M300909200)

García M, Fernández A \& Moreno JC 2014 Central hypothyroidism in children. Endocrine Development 26 79-107. (doi:10.1159/000363157)

Hennemann G, Docter R, Friesema EC, de Jong M, Krenning EP \& Visser TJ 2001 Plasma membrane transport of thyroid hormones and its role in thyroid hormone metabolism and bioavailability. Endocrine Reviews 22 451-476. (doi:10.1210/edrv.22.4.0435)

van der Heyden JT, Docter R, van Toor H, Wilson JH, Hennemann G \& Krenning EP 1986 Effects of caloric deprivation on thyroid hormone tissue uptake and generation of low- $\mathrm{T}_{3}$ syndrome. American Journal of Physiology 251 E156-E163.

Hollenberg AN 2008 The role of the thyrotropin-releasing hormone (TRH) neuron as a metabolic sensor. Thyroid 18 131-139. (doi:10.1089/thy. 2007.0251)

Horimoto M, Nishikawa M, Ishihara T, Yoshikawa N, Yoshimura M \& Inada M 1995 Bioactivity of thyrotropin (TSH) in patients with central hypothyroidism: comparison between in vivo 3,5,3'-triiodothyronine response to TSH and in vitro bioactivity of TSH. Journal of Clinical Endocrinology and Metabolism 80 1124-1128. (doi:10.1210/jcem.80.4. 7714080)

Hu Z, Zhuo X, Shi Y, Liu X, Yuan J, Li L \& Sun Y 2014 Iodine deficiency up-regulates monocarboxylate transporter 8 expression of mouse thyroid gland. Chinese Medical Journal 127 4071-4076.

Itoh H, Yura S, Sagawa N, Kanayama N \& Konihi I 2003 Hamamatsu birth cohort for mothers and children (HBC) study team neonatal exposure to leptin reduces glucose tolerance in adult mice. Journal of Endocrinology 176 193-203. (doi:10.1677/joe.0.1760193)

Lisboa PC, Fagundes AT, Denolato AT, Oliveira E, Bonomo IT, Alves SB, Curty FH, Passos MC \& Moura EG 2008 Neonatal low-protein diet changes deiodinase activities and pituitary TSH response to TRH in adult rats. Experimental Biology and Medicine 233 57-63. (doi:10.3181/0705-RM-146)

Lowell BB, S-Susulic V, Hamann A, Lawitts JA, Himms-Hagen J, Boyer BB, Kozak LP \& Flier JS 1993 Development of obesity in transgenic mice after genetic ablation of brown adipose tissue. Nature 366 740-742. (doi:10.1038/366740a0)

Mebis L, Debaveye Y, Ellger B, Derde S, Ververs EJ, Langouche L, Darras VM, Fliers E, Visser TJ \& Van den Berghe G 2009 Changes in the central component of the hypothalamus-pituitary-thyroid axis in a rabbit model of prolonged critical illness. Critical Care 13 R147. (doi:10.1186/ cc8043)

Miura Y, Perkel VS, Papenberg KA, Johnson MJ \& Magner JA 1989 Concanavalin-A, lentil, and ricin lectin affinity binding characteristics of human thyrotropin: differences in the sialylation of thyrotropin in sera of euthyroid, primary, and central hypothyroid patients. Journal of Clinical Endocrinology and Metabolism 69 985-995. (doi:10.1210/jcem69-5-985)

Moura EG, Santos RS, Lisboa PC, Alves SB, Bonomo IT, Fagundes AT, Oliveira E \& Passos MC 2008 Thyroid function and body weight programming by neonatal hyperthyroidism in rats - the role of leptin and deiodinase activities. Hormone and Metabolic Research 40 1-7. (doi:10.1055/s-2007-1004554)

de Moura EG, Lisboa PC \& Passos MC 2008 Neonatal programming of neuroimmunomodulation - role of adipocytokines and neuropeptides. Neuroimmunomodulation 15 176-188. (doi:10.1159/ 000153422)

Oliveira E, Fagundes ATS, Alves SB, Pazos-Moura CC, Moura EG, Passos MC $\&$ Lisboa PC 2007 Chronic leptin treatment inhibits liver mitochondrial $\alpha$-glycerol- $\beta$-phosphate dehydrogenase in euthyroid rats. Hormone and Metabolic Research 39 867-870. (doi:10.1055/s-2007992131)

Pearce EN 2012 Thyroid hormone and obesity. Current Opinion in Endocrinology, Diabetes and Obesity 19 408-413. (doi:10.1097/MED. Ob013e328355cd6c)

Persani L, Borgato S, Romoli R, Asteria C, Pizzocaro A \& Beck-Peccoz P 1998 Changes in the degree of sialylation of carbohydrate chains modify the biological properties of circulating thyrotropin isoforms in various physiological and pathological states. Journal of Clinical Endocrinology and Metabolism 83 2486-2492. (doi:10.1210/jcem.83.7.4970)

Plagemann A, Heidrich I, Gotz F, Rohde W \& Dörner G 1992 Obesity and enhanced diabetes and cardiovascular risk in adult rats due to early postnatal overfeeding. Experimental and Clinical Endocrinology 99 154-158. (doi:10.1055/s-0029-1211159)

Reinehr T 2011 Thyroid function in the nutritionally obese child and adolescent. Current Opinion in Pediatrics 23 415-420. (doi:10.1097/ MOP.0b013e328344c393)

Rodrigues AL, Moura EG, Passos MCF, Dutra SC \& Lisboa PC 2009 Postnatal early overnutrition changes the leptin signalling pathway in the hypothalamic-pituitary-thyroid axis of young and adult rats. Journal of Physiology 587 2647-2661. (doi:10.1113/jphysiol.2009.169045)

Rodrigues AL, Moura EG, Passos MCF, Trevenzoli IH, da Conceição EP, Bonono IT, Neto JF \& Lisboa PC 2011 Postnatal early overfeeding induces hypothalamic higher SOCS-3 expression and lower STAT-3 activity in adult rats. Journal of Nutritional Biochemistry 22 109-117. (doi:10.1016/j.jnutbio.2009.11.013)

St Germain DL, Galton VA \& Hernandez A 2009 Minireview: defining the roles of the iodothyronine deiodinases: current concepts and challenges. Endocrinology 150 1097-1107. (doi:10.1210/en.2008-1588)

Toste FP, Alves SB, Dutra SC, Bonomo IT, Lisboa PC, Moura EG \& Passos MC 2006 Temporal evaluation of the thyroid function of rats programmed by leptin treatment on the neonatal period. Hormone and Metabolic Research 38 827-831. (doi:10.1055/s-2006-956502)

Walker P \& Courtin F 1985 Transient neonatal hyperthyroidism results in hypothyroidism in the adult rat. Endocrinology 116 2246-2250. (doi:10. 1210/endo-116-6-2246)

Wilcoxon JS \& Redei EE 2004 Prenatal programming of adult thyroid function by alcohol and thyroid hormones. American Journal of Physiology. Endocrinology and Metabolism 287 E318-E326. (doi:10.1152/ ajpendo.00022.2004)

Xiao XQ, Williams SM, Grayson BE, Glavas MM, Cowley MA, Smith MS \& Grove KL 2007 Excess weight gain during the early postnatal period is associated with permanent reprogramming of brown adipose tissue adaptive thermogenesis. Endocrinology 148 4150-4159. (doi:10.1210/ en.2007-0373)

Received in final form 19 July 2015

Accepted 21 July 2015

Accepted Preprint published online 22 July 2015 http://joe.endocrinology-journals.org

DOI: $10.1530 /$ JOE-15-0237
(C) 2015 Society for Endocrinology Printed in Great Britain 